\title{
The 5S rDNA family evolves through concerted and birth-and-death evolution in fish genomes: an example from freshwater stingrays
}

\author{
Danillo Pinhal, Tatiana S Yoshimura, Carlos S Araki and Cesar Martins
}

\begin{abstract}
Background: Ribosomal $5 S$ genes are well known for the critical role they play in ribosome folding and functionality. These genes are thought to evolve in a concerted fashion, with high rates of homogenization of gene copies. However, the majority of previous analyses regarding the evolutionary process of rDNA repeats were conducted in invertebrates and plants. Studies have also been conducted on vertebrates, but these analyses were usually restricted to the $18 \mathrm{~S}, 5.8 \mathrm{~S}$ and $28 \mathrm{~S}$ rRNA genes. The recent identification of divergent $5 \mathrm{~S}$ rRNA gene paralogs in the genomes of elasmobranches and teleost fishes indicate that the eukaryotic 5 S rRNA gene family has a more complex genomic organization than previously thought. The availability of new sequence data from lower vertebrates such as teleosts and elasmobranches enables an enhanced evolutionary characterization of $5 \mathrm{~S}$ rDNA among vertebrates.
\end{abstract}

Results: We identified two variant classes of $5 \mathrm{~S}$ rDNA sequences in the genomes of Potamotrygonidae stingrays, similar to the genomes of other vertebrates. One class of $5 S$ rRNA genes was shared only by elasmobranches. A broad comparative survey among 100 vertebrate species suggests that the 5S rRNA gene variants in fishes originated from rounds of genome duplication. These variants were then maintained or eliminated by birth-anddeath mechanisms, under intense purifying selection. Clustered multiple copies of $5 \mathrm{~S}$ rDNA variants could have arisen due to unequal crossing over mechanisms. Simultaneously, the distinct genome clusters were independently homogenized, resulting in the maintenance of clusters of highly similar repeats through concerted evolution.

Conclusions: We believe that $5 \mathrm{~S}$ rDNA molecular evolution in fish genomes is driven by a mixed mechanism that integrates birth-and-death and concerted evolution.

\section{Background}

The nuclear ribosomal DNA (rDNA) is organized into two distinct multigene families comprising the so-called $45 \mathrm{~S}$ and $5 \mathrm{~S}$ rDNA repeats. The $45 \mathrm{~S}$ rDNA repeats contain the genes that are transcribed into $18 \mathrm{~S}, 5.8 \mathrm{~S}$ and 26S-28S rRNA and spacers (IGS, ITS1 and ITS2), whereas $5 \mathrm{~S}$ rDNA encodes the $5 \mathrm{~S}$ rRNA transcribing region (120 bp long and highly conserved) and a variable nontranscribed spacer (NTS) [for a review, see 1]. A common characteristic of 5S rDNA is multiple tandemly arrayed repeats, at one or several chromosomal locations throughout the genome. Furthermore, the 5S

\footnotetext{
* Correspondence: cmartins@ibb.unesp.br

UNESP - Universidade Estadual Paulista, Instituto de Biociências,

Departamento de Morfologia, Botucatu, SP, Brazil
}

rDNA has been reported to be linked to other genes or arranged as a spread of additional copies [2].

Based on the supposed homogeneity among $5 \mathrm{~S}$ rDNA repeats, several studies propose that $5 \mathrm{~S}$ rDNA are subject to concerted evolution [3-5], where duplicated gene family members evolve as a single unit that undergoes a high degree of homogenization (as a unit in concert). A combination of unequal exchange and gene conversion within and between the same chromosome loci have been suggested to explain how such evolution can occur "in concert" [6,7]. A key difference between theses mechanisms is that gene conversion maintains the copy number of a gene, whereas unequal crossing over may increase or decrease the gene copy number from generation to generation.
C Biomed Central

C 2011 Pinhal et al; licensee BioMed Central Ltd. This is an Open Access article distributed under the terms of the Creative Commons Attribution License (http://creativecommons.org/licenses/by/2.0), which permits unrestricted use, distribution, and reproduction in any medium, provided the original work is properly cited. 
However, the diverse molecular features exhibited by the $5 \mathrm{~S}$ genes and spacers bring into question the assumption that there is concerted evolution in $5 \mathrm{~S}$ rDNA. First of all, the majority of the findings on concerted evolution of rDNA were based on the major ribosomal $18 \mathrm{~S}, 28 \mathrm{~S}$ and $5.8 \mathrm{~S}$ units, which differ from $5 \mathrm{~S}$ rDNA in number of repeats, genomic organization and transcriptional machinery. Not all mechanisms that affect major ribosomal genes may act on $5 \mathrm{~S}$ rDNA arrays. Moreover, molecular analyses have demonstrated the existence of remarkable $5 \mathrm{~S}$ rDNA variants [8-13] within individuals and species of plants [14,15], fungi [16,17] and animals [18-21]. Generally, these 5S rDNA variants correspond to paralogs copies that are clustered or dispersed in the genome. In several vertebrate groups, the main difference between $5 \mathrm{~S}$ rDNA variants involves the length of the NTS, and are mostly due to single mutations or indels, whereas the transcribed regions of $5 \mathrm{~S}$ rRNA are not divergent. Conversely, in studies of marine and freshwater fish [22-28], including members of the elasmobranch group such as sharks and rays [29-31], significant variation has been found in spacer sequences and even in the $5 \mathrm{~S}$ rRNA genes. An extensive analysis of nucleotide sequences and chromosomal in situ hybridization, also in fish, demonstrated that such variant forms correspond to two classes of $5 \mathrm{~S}$ rDNA repeats, each organized separately in the genome [see 30, for review]. Two classes of 5S rDNA were also observed in Xenopus; the first was expressed in somatic cells and the second, which was derived from the somatic type by gene duplication, was expressed in oocytes [21]. Together, these findings suggest that, aside from the mechanisms of the classical Dover-Arnheim model of concerted evolution, additional mechanisms are likely involved in the evolution of $5 \mathrm{~S}$ rDNA.

Based on the evidence presented above, 5S rDNA families also have been proposed to evolve according to an evolutionary process known as birth-and-death [16,32-34]. In the birth-and-death model of evolution, new genes are created by repeated gene duplication at different genomic locations, and some of the duplicated genes are maintained in the genome for a long time, while others are deleted or become nonfunctional. On the other hand, homogeneity is maintained by the effects of strong purifying selection, and as a result, the DNA sequence of different members of the same gene family can be very different, both within and between species [33]. Consequently, high levels of intragenomic repeat variation are expected in the $5 \mathrm{~S}$ rDNA repeats that evolve through birth-and-death process, leading to the accumulation of numerous $5 \mathrm{~S}$ ribosomal gene and spacer variants [35]. To distinguish between concerted evolution and evolution by gene birth-and-death, knowledge about the level of repeat variation and the phylogenetic patterns between species is critical.

Studies of the structure and organization of $5 \mathrm{~S}$ rDNA in the genome of chondrichthyans, a long-lived, welladapted vertebrate group, are limited to a few marine families such as the Rajidae [29] and Carcharhinidae [30-32]. Similar to bony fishes, the genomes of sharks and rays also seems to harbor a dual $5 \mathrm{~S}$ rDNA system [29], although additional variant copies have been detected in other species [36]. Furthermore, a distinctive $5 \mathrm{~S}$ rRNA gene class shared only by elasmobranch species [30] suggests a group-specific evolutionary history of $5 \mathrm{~S}$ rDNA, making these organisms of special interest for deciphering the genomic architecture of multigene families.

In the present paper, we investigated the genomic organization of $5 \mathrm{~S}$ rDNA tandem repeats in members of the Potamotrygonidae family, who comprise the only group of rays that is totally restricted to freshwater systems $[37,38]$. These rays belong to the Myliobatiformes order as well, a large group of predominantly marine elasmobranches [39]. In our discussion, we focus on a model for the ongoing evolution of the 5S rRNA genes among elasmobranches. We also performed a comparative genomic analysis of $5 \mathrm{~S}$ rRNA genes from several fish orders, as well as from other, unrelated vertebrates, in an attempt to measure the contribution of genomic events to the diversification of the $5 \mathrm{~S}$ rRNA multigene family in long-term evolution.

Our results identified two types of $5 \mathrm{~S}$ rDNA tandem repeats in stingrays, as was previously observed in teleosts and other elasmobranches. Nucleotide polymorphisms in the $5 \mathrm{~S}$ rDNA sequences were also valuable as molecular markers to distinguish different genera and species of Potamotrygonidae stingrays. Finally, the large vertebrate dataset of $5 \mathrm{~S}$ rDNA sequences examined support the idea that this multigene family evolves in the fish genomes according to a mechanism integrating both birth-and-death and concerted evolution.

\section{Results}

\section{S rDNA organization in Potamotrygonidae stingrays}

Electrophoresis of PCR products from the $5 \mathrm{~S}$ rDNA of Potamotrygonidae stingrays on ethidium bromide stained gels revealed the existence of two fragments of different sizes. A shorter fragment of $\sim 450 \mathrm{bp}$ in length was common to the three species, while larger fragments of $\sim 1,800 \mathrm{bp}$ in length were found in the congeners P. motoro and P. falkneri, and of $\sim 1,700 \mathrm{bp}$ in length in $P$. aiereba (Figure 1). Using BLASTn, sequences of several positive clones were confirmed to be $5 \mathrm{~S}$ rDNA repeat units, each consisting of a $5 \mathrm{~S}$ rRNA gene (120 bp) and an adjacent NTS of highly variable length (Table 1) (Genbank accession numbers 
a)

b)
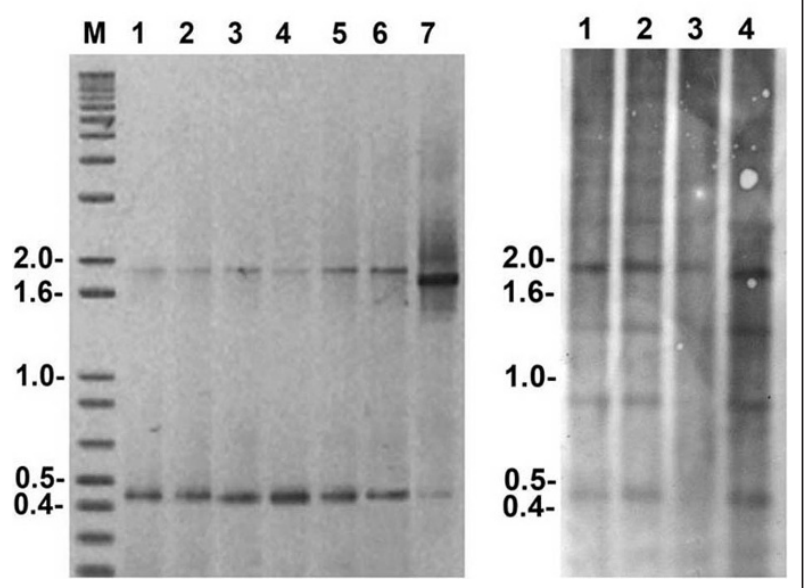

Figure 1 PCR products and Southern blot probed to 5S rDNA of stingrays. (a) PCR amplicons of $5 S$ rDNA repeats from freshwater stingrays submitted to garose gel electrophoresis. 1-3, Potamotrygon motoro; 4-6, Potamotrygon falkneri; 7, Paratrygon aiereba. (b) Southern blot hybridization of Hindlll digested genomic DNA of $P$. falkneri (1), P. motoro (2 and 3) and P. aiereba (4) probed with $5 S$ rDNA class I of $P$. motoro. Bands of distinct molecular weight correspond to monomeric, dimeric, trimeric and tetrameric units, indicating sequence variants lacking the Hindlll restriction site or undigested products. M, molecular marker with base pair sizes showed on the left.

JF92309-JF92336). We named the shorter and the larger fragments as $5 \mathrm{~S}$ rDNA class I and $5 \mathrm{~S}$ rDNA class II, respectively. The coding regions and nontranscribed spacers of the $5 \mathrm{~S}$ rDNA class I were completely sequenced, (i.e., all $450 \mathrm{bp}$ were recovered). However, from $5 \mathrm{~S}$ rDNA class II clones, we were able to obtain the sequence of the entire coding region but only a partial segment of the NTS, for a total of 650 bp. After removing the non-informative primer

Table 1 Number of clones (NC), size (SL) and genetic distance (GD) of 5 S rDNA units in Potamotrygonidae stingrays

\begin{tabular}{lcccccc}
\hline & \multicolumn{3}{c}{ 5S rDNA classe I } & \multicolumn{3}{c}{ 5S rDNA classe II } \\
\cline { 2 - 7 } & NC & SL & GD & NC & SL & GD \\
\hline 5S rRNA gene & & & & & & \\
P. falkneri & 06 & 77 & 0.012 & 03 & 77 & 0.018 \\
P. motoro & 06 & 77 & 0.040 & 06 & 77 & 0.000 \\
P. aiereba & 02 & 77 & 0.000 & 07 & 77 & 0.029 \\
Overall average & 14 & 77 & 0.017 & 16 & 77 & 0.016 \\
\hline NTS & & & & & & \\
P. falkneri & 06 & $360-361$ & 0.009 & 04 & $592-594$ & 0.023 \\
P. motoro & 06 & $360-361$ & 0.003 & 06 & $586-604$ & 0.029 \\
P. aiereba & 02 & 369 & 0.014 & 06 & $565-609$ & 0.035 \\
Overall average & 14 & $360-369$ & 0.016 & 16 & $565-609$ & 0.078 \\
\hline
\end{tabular}

$\mathrm{NC}$, number of clones; SL, Sequence length; GD, Genetic distance annealing regions, we analyzed a 77 bp segment of the 5S rRNA gene (see additional file 1: Final alignment of nucleotide sequences encompassing the class I and class II 5S rRNA genes from the three Potamotrygonidae stingrays), plus a NTS segment of variable length in several clones from three individuals of each species (Table 1, see additional file 2: NTS class I and NTS class II nucleotide sequences from the stingray species included in this study), from both $5 \mathrm{~S}$ rDNA classes. It is worth noting that the $77 \mathrm{bp}$ segment we analyzed completely covers the internal control regions (ICRs), which are considered key regions of $5 \mathrm{~S}$ genes due to their active role as transcriptional promoters. The A box is a general ICR sequence for RNA polymerase III. The intermediate element (IE) and the C box are specific to $5 \mathrm{~S}$ rRNA transcription and work as binding sites for the transcription factor TFIIIA [40].

The subsequent alignment of Potamotrigonidae 5S rRNA genes allowed us to identify two types of sequences that are somewhat distinct. These stingray sequences probably correspond to functional genes because they encompass the internal control regions (ICR) within the coding segment (i.e., box A, internal element and box $\mathrm{C}$ ) and the poly- $\mathrm{T}$ motif at the end of the coding region. We also found the $5 \mathrm{~S}$ genes to be GC-rich (53.3\% to the class I and 58.4 to the class II). Only two nucleotide polymorphisms, at positions 60 and 112 (a G-A transition, and a C-A transversion, respectively), characterized both sequences in the two classes from the three species (Figure 2, see additional file 1: Final alignment of nucleotide sequences encompassing the class I and class II 5S rRNA genes from the three Potamotrygonidae stingrays).

Numerous dispersed non-parsimony informative mutations were also found in each $5 \mathrm{~S}$ gene class. The genetic variation was lower when comparing $5 \mathrm{~S}$ gene classes in Paratrygon. The overall genetic distance of coding sequences among the three species was also low, with a mean of 0.17 and 0.16 for class I and class II, respectively (Tables 1 and 2). Among the ICRs, we detected extensive nucleotide variation within the $\mathrm{A}$ and $\mathrm{C}$ boxes and a unique polymorphism within the internal element (Figure 2, Table 2, see additional file 1: Final alignment of nucleotide sequences encompassing the class I and class II 5S rRNA genes from the three Potamotrygonidae stingrays).

Southern blot hybridization experiments confirmed the existence of two 5S rDNA classes in Potamotrygonidae composed of tandem repeats of $\sim 450 \mathrm{bp}$ and $\sim 1,700$ to $1,800 \mathrm{bp}$. This finding is further supported by the PCR products and the sequencing data obtained (Figure 1).

In contrast to the way the $5 \mathrm{~S}$ rRNA genes within and between $5 \mathrm{~S}$ rDNA classes were conserved or only moderately variable, we discovered two very distinct NTS 


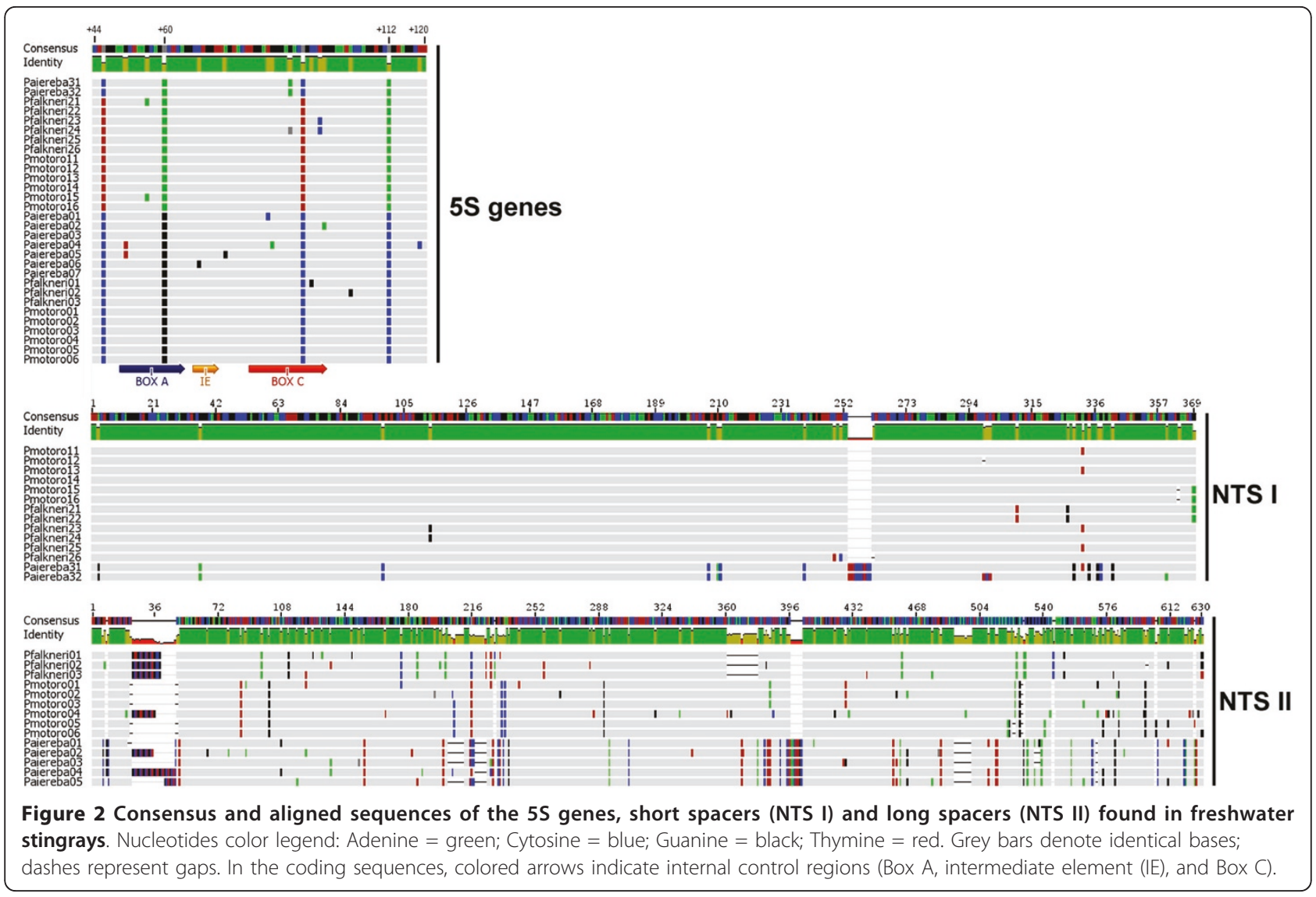

types in the genomes of the three stingrays. Furthermore, data mining showed that NTS sequences isolated from Potamotrygonidae do not match any nucleotide sequence currently in the NCBI database.

We detected a high degree of sequence-length polymorphism within the two NTS classes. Class I spacers had 12 nucleotides substitutions plus six extra bases (a TCC repeat), which distinguishes $P$. aiereba from the other Potamotrygon species, whereas the two congeners had no species-specific nucleotides (see additional file 2: NTS class I and NTS class II nucleotide sequences from the stingray species included in this study). Despite partial sequencing, the large NTS class II had several interspecific polymorphisms, which allowed the congeners of P. motoro and P. falkneri spacer sequences to be discriminated (see additional file 2: NTS class I and NTS class II

Table 2 Polymorphism ( $\pi$, bold values), divergence ( $K$, lower diagonal) and fixed differences (upper diagonal) in 5S rRNA genes among stingrays

\begin{tabular}{llll}
\hline & P. aireba & P. falkneri & P. motoro \\
\hline P. aiereba & $\mathbf{0 . 0 3 8 4 9} \pm \mathbf{0 . 0 0 7}$ & 0 & 0 \\
P. falkneri & $0.05405 \pm 0.002$ & $\mathbf{0 . 0 4 1 9 5 \pm 0 . 0 0 9}$ & 0 \\
P. motoro & $0.04268 \pm 0.001$ & $0.03530 \pm 0.001$ & $\mathbf{0 . 0 3 1 6 4 \pm 0 . 0 0 4}$ \\
\hline
\end{tabular}

nucleotide sequences from the stingray species included in this study). Both NTS classes had a high GC content (class $\mathrm{I}=56.3 \%$ and class II $=59.7 \%$ ), comparable to the $5 \mathrm{~S}$ gene. This was unexpected because GC-rich regions are predominantly found inside coding sequences. Table 1 shows the analysis of several intraspecific parameters. We detected low similarity between orthologs class II NTS regions, which is in contrast to how highly conserved between Potamotrygon and Paratrygon genera the class I regions are. The highly polymorphic class II spacers contrast with the homogenous spacers of class I (Table 1, Figure 2). Indels and nucleotide substitutions further increase genetic distance within NTS type II sequence (Figure 2, see additional file 2: NTS class I and NTS class II nucleotide sequences from the stingray species included in this study). The estimates of average evolutionary divergence between all NTS sequence pairs were much higher in the larger spacers (NTS I: $0.016 \pm$ 0.003; NTS II: $0.081 \pm 0.009$ ).

We conducted intra- and interspecific analyses between the two paralogs NTS classes independently. Intraspecific nucleotide diversity in stingrays was always less than 0.03 ; however, the percentage of polymorphisms was consistently beneath $7 \%$. These data suggest the occurrence of several variants that are different by 
only one or a few nucleotides. Furthermore, simple sequence repeats (SSRs) that represent highly mutable DNA sequences were detected in the NTS II class and significantly contributed to the observed intra- and interspecies nucleotide variation (Figure 2). In a detailed analysis of the NTS II, we identified several tri- and dinucleotide SSRs composed of TGC and AC/GC motifs, respectively, which may be responsible for the high number polymorphisms observed. Finally, indel blocks outside the SSRs ranging from 7 to $18 \mathrm{bp}$ were found to exist either in Potamotrygon or in Paratrygon sequences (see additional file 2: NTS class I and NTS class II nucleotide sequences from the stingray species included in this study).

Phylogenetic inferences based on the $5 \mathrm{~S}$ genes and NTSs of Potamotrygonidae stingrays

We performed independent phylogenetic analyses of the $5 \mathrm{~S}$ genes and the NTS sequences, between and within each Potamotrygonidae species (Figures 3 and 4). Modeltest 3.6 [41] determined that the Transitional Model with Equal Frequencies (TIMef) was the best model for the evolution of $5 \mathrm{~S}$ genes; however, for the NTS, Felsentein 81 (F81) was the best fitting model. Both models incorporate rate variation among sites $(+G)$.

Applying these parameters to all examined specimens supports the existence of two classes of $5 \mathrm{~S}$ rDNA that are well separated into distinct clades in the phylogenetic trees for the $5 \mathrm{~S}$ genes and the NTS (Figures 3 and 4 , respectively). Phylogenetic data showed that variability in the NTS is responsible for the separation of $5 \mathrm{~S}$ rDNA into two classes. However, the 5S rRNA genes also harbor polymorphisms that differentiate them into two classes (classes I and II), as illustrated by the high probability values for the BI, ML and MP trees (Figure 3). Analyzing the relationships in the $5 \mathrm{~S}$ rRNA gene tree, we determined that the class I genes from $P$. aiereba branched from the Potamotrygon species class I genes due to two transitions at positions 46 and 92 (Figure 2). In the corresponding positions, $P$. aiereba carries the same two nucleotides shared by its class II genes, as well as by the class II genes of all Potamotrygon individuals (see additional File 1: Final alignment of the nucleotide sequences of the $5 \mathrm{~S}$ rRNA class II and class I genes from three Potamotrygonidae stingrays). The class II genes from all individuals do not cluster according to species boundaries, with intermingling between classes (Figure 3). This finding indicates that most of the phylogenetic relationships seen are likely not significant, and therefore, only the differentiation between variant copies of class I and II genes is well supported.

When evaluating NTS data, the $P$. aiereba spacers always cluster in a separate branch from those of the Potamotrygon species. The ML tree of NTS class I

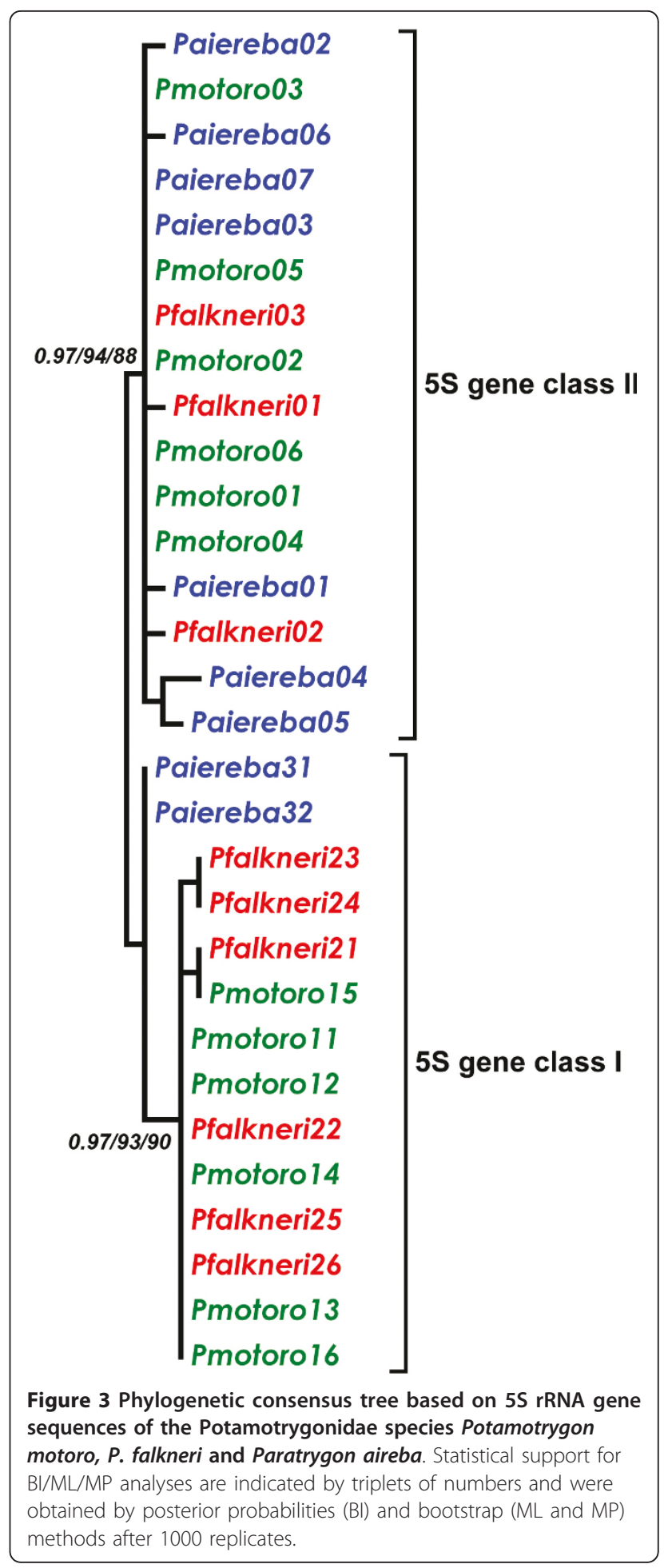

sequence clearly identified two clades of sequences (Figure 4). One clade was comprised of the P. aiereba NTS I sequences, which branched out according to species boundaries. The other clade was composed of intermingled sequences from the two Potamotrygon species. 


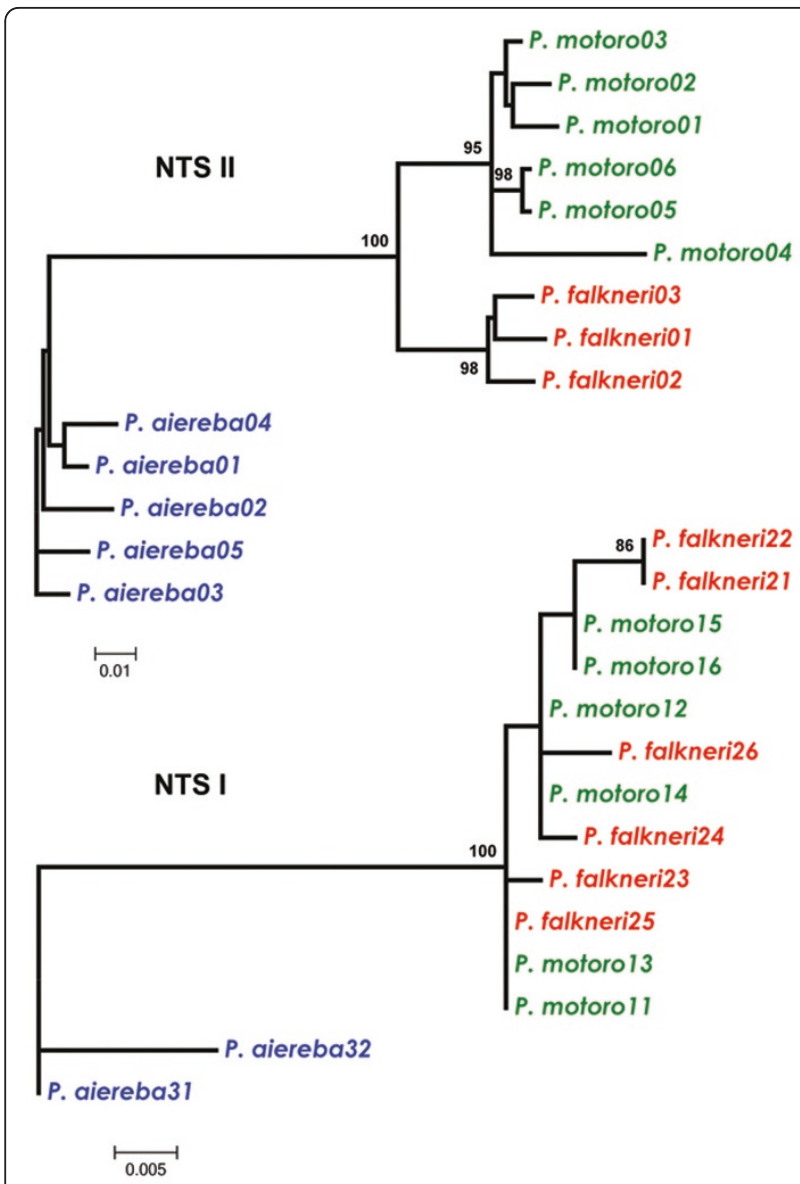

Figure 4 Maximum-likelihood trees of the two types of NTS sequences, NTS class I and NTS class II. Values represent nodes recovery percentages after 1000 bootstrap replicates. Bootstrap values under $50 \%$ are omitted.

In contrast, the comparison of NTS class II sequences produced a tree that was more informative in distinguishing the relationship between the three species (Figure 4), as all branches obtained very high statistical support.

\section{Phylogenetic analysis of vertebrate $5 \mathrm{~S}$ genes}

We verified several divergent vertebrate clades using a Bayesian tree, and by examining the alignment of $5 \mathrm{~S}$ coding sequences (Figure 5, see additional file 3: Alignment of 5S rRNA gene sequences from several vertebrates). The most basal division we could detect was between jawless fish such as lampreys (Agnathans) and jawed vertebrates (Gnathostomata). A consistent phylogenetic signal ( $83 \%$ posterior probability) supports a clade containing only the Elasmobranchii, except for the class II sequences from Raja asterias and the class I sequences from Rhizoprionodon lalandii and R. porosus, which clustered in a separate branch with Teleostei. Moreover, the "elasmobranch clade" splits into two subclades comprising the shark and Potamotrygonidae class I genes (65\% posterior probability) as a sister branch of the Rajidae and Potamotrygonidae class II genes. Therefore, both $5 \mathrm{~S}$ gene variants in Potamotrygonidae stingrays were placed in the elasmobranch clade, joining either sharks or rays (Figure 5). In another clade, the $5 \mathrm{~S}$ genes of Ray-finned fishes, represented by Chondrostei (Acipenseriformes) and two Teleostei (Gasterosteiformes and Siluriformes), intermingled with Tetrapoda (Reptilian, Amphibian, Avian and Mammal). The remaining Teleostei fish $5 \mathrm{~S}$ gene sequences clustered into a single clade with the $5 \mathrm{~S}$ gene class genes from Raja asterias, R. lalandii and R. porosus (Figure 5).

\section{Discussion}

\section{Molecular organization, evolution and biological} significance of the two 5S rDNA arrays in stingrays

The cause of the widespread appearance of distinct classes of $5 \mathrm{~S}$ rDNA repeats in the genomes of vertebrate species is unknown. In fishes, distinct classes of $5 \mathrm{~S}$ rDNA have already been found in several Actinopterygii and Elasmobranchii. Usually, the variation in $5 \mathrm{~S}$ rDNA is related to the high polymorphism in the NTS regions, whereas the $5 \mathrm{~S}$ coding region remained unchanged [25,42]. However, in Merlucius fishes [28], Rajidae rays [29] and Carcharhinidae sharks [30,31], 5S genes were found to be quite divergent between variant classes and still functional.

In this paper, we identified the characteristic $5 \mathrm{~S}$ rDNA dual system in the three freshwater stingray genomes $(P$. motoro, P. falkneri and P. aiereba) as determined by PCR, sequencing and Southern blotting. Interspecific examination of the two classes of $5 \mathrm{~S}$ rDNA revealed notable dissimilarities between NTS I and II classes, in agreement with previously published data [24-26]. By contrast, we found a low quantity of intraspecific variation within each NTS class, where sequence homogenization was more intense. The notable genetic distances found in the between-classes comparison (NTS I sequences had 0.016 and NTS II had 0.078 of overall genetic distance) suggest that both NTS classes are under distinct genomic pressures. It is interesting to note that the shorter NTS (NTS I) has been extensively homogenized when compared to the longer NTS II. The low level of variation in the NTS I could be related to selective pressure against major changes that could disrupt essential regulatory elements present on this NTS. It has been argued that a minimum NTS size is necessary for the maintenance of $5 \mathrm{~S}$ rDNA repeats in the genome [43] because the NTSs could contain DNA elements involved in the regulation of $5 \mathrm{~S}$ rRNA gene expression $[44,45]$. On the other hand, the variable levels of homogenization of NTSs I and II (and consequently of both $5 \mathrm{~S}$ rDNA classes) could be explained by the clustering of each class in distinct 


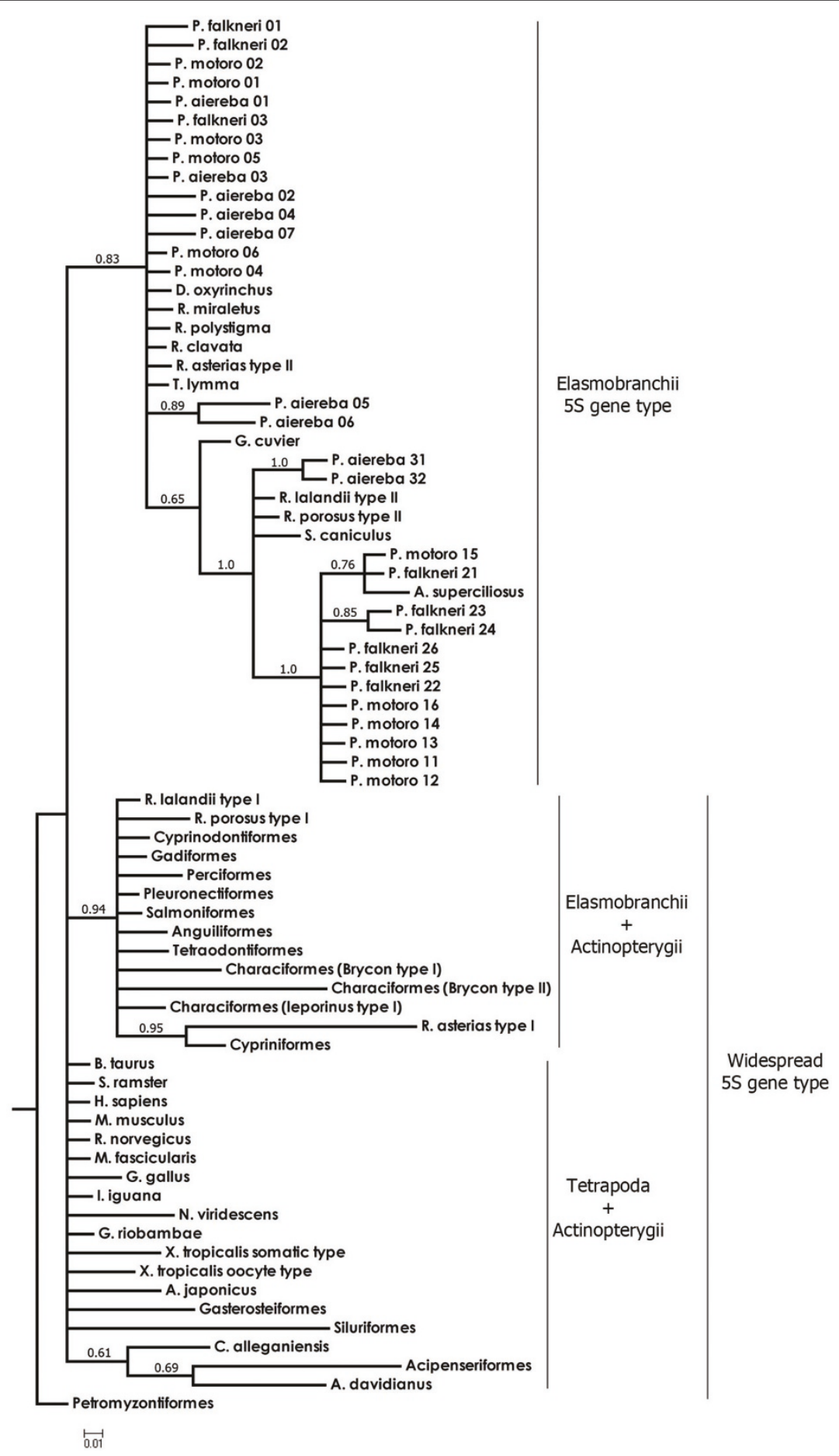

Figure 5 Bayesian phylogenetic tree for 100 vertebrate species based on $5 \mathrm{~S}$ gene sequences using lampreys (Agnatha) as outgroup of all the other (Gnathostomata). Values represent nodes posterior probability support recovered in the Bayesian analysis.

genomic environments under constraint from different evolutionary forces.

In sharks, the ancestral $5 \mathrm{~S}$ class I genes derive from different duplicated genes that originated before the separation of the Agnathans and the Gnathostomans species [30]. In contrast, although there was a slight variation in the $5 \mathrm{~S}$ rRNA genes of stingrays, they still corresponded to a single gene type, noticeably, the elasmobranch type. Stingrays do not appear to carry the ancestral $5 \mathrm{~S}$ gene class I in their genomes, indicating 
that it may have been lost in the course of evolution due to a lack of functional constraint. Within the Elasmobranchii group, stingrays can be considered a modern division that irradiated approximately 19 mya from a marine ray ancestor [46,47], 180 mya after the separation of Batoidea (rays) and neoselachians (sharks) in the basal Jurassic or late Triassic periods [48]. Marine stingrays studied thus far have an ancestral class I gene; therefore, the loss of this gene variant in freshwater stingrays may have occurred later, during the evolutionary transitions from marine to freshwater habitats. Bearing in mind that variant copies of $5 \mathrm{~S}$ rRNA multigene families are commonly found dispersed across vertebrate genomes, the birth-and-death of genes following mutational events perhaps led to the loss of the ancestral class I gene (Figure 6). Given that new gene clusters arise mostly by chance, the initial evolution of classes within multigene families may be casual. Moreover, considering the feasibility of transposition of the $5 \mathrm{~S}$ rRNA genes $[49,50]$, new genes could arise by new fixation of unfastened short number copies from pre-existent tandem arrays (e.g., the class II arrays). Afterward, duplications would spread, and these genes would form a new cluster, as can be observed in other multigene families [51,52]. Thus, functional or even non-functional sequences could be kept and homogenized by gene conversion and unequal crossing over via the process of concerted evolution, leading to the current set of observed variant gene classes. Similarly, non-functional variant copies of $5 \mathrm{~S}$ rDNA repeats could also spread and give rise to several new clusters in the genome, as observed in the Hoplias malabaricus fish [53].

It still remains unclear whether the two $5 \mathrm{~S}$ rDNA classes of vertebrates are both related to the canonical role of ribosomal RNAs or represent a distinct biological feature. The occurrence of $5 \mathrm{~S}$ genes that are differentially regulated in somatic and oocyte cells [21] has been explored as the reason for the dual $5 \mathrm{~S}$ rDNA pattern reported in fish. However, neither the somatic nor the oocyte types are correlated with the divergent $5 \mathrm{~S}$ rDNA classes detected in diverse fish groups [30] as well as the Potamotrygonidae stingrays.

Among fishes, chromosomal data support the idea that the divergence of different classes of $5 \mathrm{~S}$ rDNA

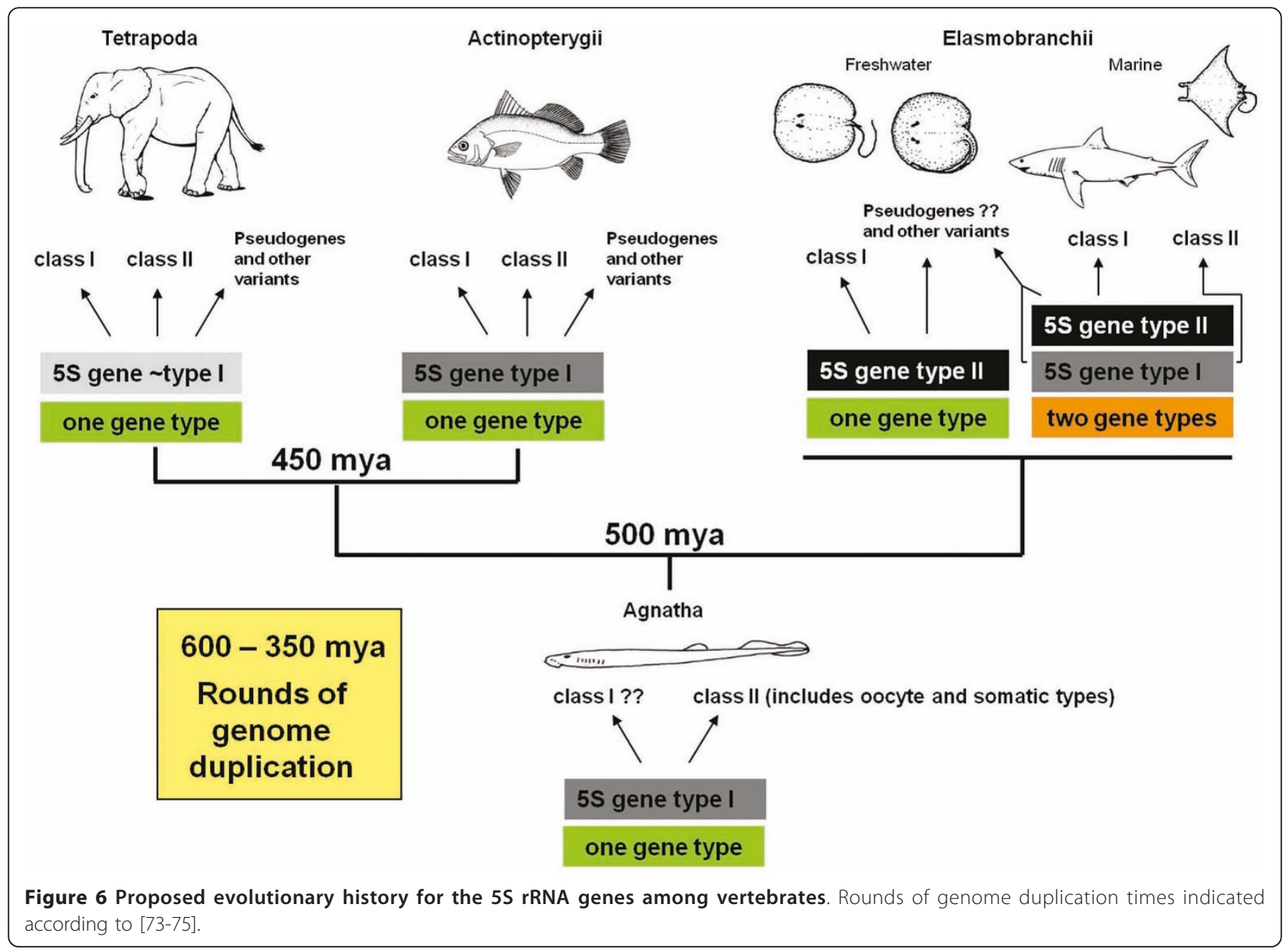


constitutes a widespread form of organization, and is related to their presence in different chromosomal regions [25]. Nevertheless, even divergent 5S rDNA types that differ profoundly in their spacer sequences and genomic environments may be situated on the same chromosome [42,54]. Differently sized units may be arranged in composite tandem arrays, as is seen in several species of plants [55], such as in Vitis vinifera, where three different $5 \mathrm{~S}$ rDNA units coexist within the same tandem array [56]. The same arrangement has been observed in six Mugilidae fishes of the genera Liza and Chelon, where two types of $5 \mathrm{~S}$ rDNA repeat units were characterized by an intermixed arrangement within a single chromosome locus [27].

In the Potamotrygonidae, although we do not have direct evidence of how the two 5S rDNA tandem arrays are clustered, we have some evidence that they are disconnected. First, we did not observe any evidence of an intermixed arrangement of $5 \mathrm{~S}$ rDNA classes I and II from the PCR or Southern blot results. If $5 \mathrm{~S}$ rDNA type I and II were intermixed, we would obtain different band patterns, rather than the classical tandem repeat patterns observed. Furthermore, the intraspecific comparison of different classes revealed a high dissimilarity between them, which suggests they occupy distinct chromosome locations.

Data accumulated to date demonstrates that the presence of two distinct classes of 5S rDNA arrays in elasmobranches and teleost fishes is a general trend (Figure 6). Such variation may be a consequence of ancient diversification of $5 \mathrm{~S}$ rDNA repeat types and its fixation in the main lineages of vertebrates. The intense genomic dynamism that seems to guide the evolution of tandem repeat elements may have generated the divergent copies of 5S rDNA observed. Some authors [57] speculate that the newly generated duplicate genes or gene families may evolve to interact with other existing gene families and promote the adaptation of organisms to new environments. However, there are no substantial evidences for such a conclusive statement, and, therefore, the major biological reason for such a dual pattern of $5 \mathrm{~S}$ rDNA organization remains unknown.

\section{S rDNA as phylogenetic and phylogeographic tool and its utility for the molecular identification of stingrays} The 5S rDNA polymorphisms were efficient markers for the discrimination of genera and species of potamotrygonids. The two $5 \mathrm{~S}$ rDNA classes characterized in $P$. motoro, $P$. falkneri and $P$. aiereba represent paralogs and should be treated as two different nuclear markers. Nucleotide-level and sequence length variation generate distinct profiles by PCR (Figure 1) and in phylogenetic trees (Figure 4), which is useful for distinguishing between Potamotrygon and Paratrygon species.
Unfortunately, we were not able to identify the three species using PCR alone, as can be done for a few shark species [36].

Although the NTS I class sequences were highly uniform within the Potamotrygon genus, a few consistent polymorphisms were enough to detach them from Paratrygon. By contrast, intraspecific nucleotide variability was 5-fold higher in NTS II class than in NTS I; therefore, NTS I can be used to discriminate $P$. aiereba from the Potamotrygon spp. Alternatively, NTS II discriminates all potamotrygonid species and represents an excellent marker to access species identification within this group.

$5 \mathrm{~S}$ rDNA sequences and the NTS segments in particular have been successfully applied to the identification and inspection programs intended to assess the identity of species and hybrids $[36,58,59]$, as well as in fish phylogeography [60] and phylogenetic inference studies $[29,61]$. In Potamotrygonidae, short and long repeats may also correspond to informative markers at the population level and may be used in combination with mitochondrial markers in a more consistent dual analysis. Further independent characterization of each $5 \mathrm{~S}$ rDNA class in stingray populations from distinct areas would provide a better basis for phylogeographic studies. Hence, the development of new genetic markers is a welcome contribution to the study of phylogeny, phylogeography and identification in potamotrygonids species.

\section{A mixed model for the evolution of 5S rDNA}

Several mechanisms are believed to act in the evolution of multigene families and duplicated sequences, driving their accumulation, divergence or even deletion from the genome. The model of concerted evolution was originally thought to apply to gene families that are responsible for producing a large quantity of the same gene product, as in the case of rRNA genes [62].

Since the concerted evolution theory explains the observed lack of genetic variability among rRNA gene copies in many different species, it became a universal accepted as the unique mode of evolution of rRNA multigene families [63-65].

Although concerted evolution explains sequence homogenization among members of a repeated gene family, a pair of paralog gene sequences can diverge fast enough to escape gene conversion [66]. When this happens, the rate of homogenization may be too low to prevent significant levels of intraspecific rDNA polymorphisms. If this is the case, the production and maintenance of a large quantity of the same gene product can also be achieved by strong purifying selection, without concerted evolution [57]. When concerted evolution takes place, it will homogenize the gene copies that are arrayed in the same cluster, and this cluster can 
differ significantly from paralogs copies of a second cluster. Thus, new genes are created by gene duplication, and some duplicated genes are maintained in the genome for a long time, but other genes are deleted or become nonfunctional (e.g., pseudogenes) through deleterious mutations.

Most studies in teleost fish have shown that a majority of 5S rRNA multigene families evolve in a rigorously concerted fashion. However, the presence of several $5 \mathrm{~S}$ rDNA variants has been reported in such diverse taxa as molluscs [8,12,13,67], echinoderms [68] and arthropods [10]. Among fishes, highly variable paralogs have been clearly documented in the $5 \mathrm{~S}$ rDNA regions in species of the Leporinus genus [25], in the Nile tilapia Oreochromis niloticus [42], in Merlucius species [28], distinct Actinopterygii fish orders $[9,24]$ and in marine Elasmobranchii $[29,30]$. Our data advocate the hypothesis that independent mechanisms guide the evolution of distinct $5 \mathrm{~S}$ rDNA classes in the genome of stingrays, which are likely maintained by both concerted and birth-and-death evolution, as was reported for bitterling (Cyprinidae) fish [69].

In fact, a variety of studies have shown that rDNA and other multigene families can evolve through distinct mechanisms, leading to evolutionary patterns other than concerted evolution. Highly conserved histone and ubiquitin gene families are well-defined examples of birthand-death evolution [34,70-72]. For example, small gene families with strong purifying selection, such as the heat shock protein [73] and amylase gene families [74], evolve through a mix of evolutionary processes.

The presence of pseudogenes in a multigene family strongly suggests that the family evolves by a birth-anddeath process [16]. There are numerous reports of rRNA pseudogenes where the coding regions do not have functional constraints [10,75-77]. In fish, diverse studies have reported the presence of $5 \mathrm{~S}$ rDNA pseudogenes $[24,28,42,69]$. In Potamotrygonidae, no evidence of pseudogenes was found, most likely because both primers anneal in the 5S rRNA gene, and the presence of mutations in the gene would have considerably reduced the likelihood that pseudogenes would have been amplified, cloned, and sequenced [35]. A larger genomic survey in the future could be useful to detect pseudogenes in stingrays.

Under the concerted evolution model, genes cluster according to species; however, they do not under the birth-and-death model, except in cases of recent gene duplication [16]. The variant sequences of $5 \mathrm{~S}$ rDNA from the three different stingray species clustered according to classes but not to species. These findings indicate that birth-and-death processes have been active throughout Potamotrygonidae 5S rDNA evolution. Conversely, nucleotide diversity values calculated for species within each clade were relatively small, implying that homogenizing forces diminished sequence divergence locally within each separate cluster of $5 \mathrm{~S}$ rDNA variants in each species. Such a pattern fit in a mixture of concerted and birth-and-death evolution, where distinct arrays tend to accumulate large amounts of variation that is kept or lost due to purifying selection. However, paralogs copies in the genome, representing distinct $5 \mathrm{~S}$ rDNA arrays, appear to undergo array-specific concerted evolution rather than a single homogenization mechanism common to all arrays.

To understand the evolutionary dynamics of 5S rRNA genes, we carried out a large cross-species survey. Figure 5 shows the phylogenetic tree of $5 \mathrm{~S}$ genes from major vertebrate lineages. The analyses performed showed a between-species clustering of $5 \mathrm{~S}$ ribosomal DNA variants. As expected from previous studies [30], despite being distantly related, several organisms, including sharks, frogs, mice and humans, share the widespread ancestral forms of the $5 \mathrm{~S}$ genes. Furthermore, the majority of vertebrate lineages contain variant $5 \mathrm{~S}$ rDNA copies, which have differentiated from the original genes by duplication and deletion events.

Studies suggesting the occurrence of birth-and-death on rDNA arrays have been predominantly conducted using lower eukaryotes, such as studies of the $18 \mathrm{~S}$ rDNA in Apicomplexans [78], fungi [16], plants [79] and invertebrates [35], who theoretically differ from higher eukaryotes in genome dynamics. Thus, our broad survey in vertebrates can shed light on the evolution of rDNA arrays.

In Potamotrygon and Paratrygon species, as well as in sharks and teleost fish, we found several 5S rDNA variants within clusters, even in the 5S rRNA gene. Comparisons between variants demonstrated a lack of homogenization in the Elasmobranchii and Teleostei, whereas homogenizing mechanisms appeared to be active within each variant in each species. These new variants emerged sporadically during fish evolution in the main vertebrate lineages and likely originated during ancient rounds of genome duplications [80-82] acting on polymorphic ancestral $5 \mathrm{~S}$ rDNA arrays. This hypothesis is supported by phylogenetic analyses that revealed a between-species clustering of Potamotrygonidae 5S rDNA variants, which was also observed in the rDNA sequences of sharks, marine rays and several teleost fish 5S $[29,30,69,83]$. Thus, the emergence of new variants and their within-variant homogenization supports the idea that both concerted and birth-and-death evolution are responsible for the extant variation of this multigene family in fish genomes. Recently, similar results were found in invertebrates [13], suggesting that the longterm evolution of $5 \mathrm{~S}$ rDNA is most likely mediated by a mixed mechanism in which the generation of genetic 
diversity is achieved through birth-and-death. This process is then followed by the local homogenization of the paralogs units, which most likely occurs after their physical movement to independent chromosomal locations.

\section{Conclusions}

A complex combination of duplications, insertions, deletions, and general genome rearrangements has likely been involved in the evolution of the $5 \mathrm{~S}$ rRNA gene family in vertebrates. The present work reveals that in fishes, different classes of 5S rDNA are organized in distinct clusters that arose from duplications and are kept or lost by purifying selection under birth-and-death evolution. Simultaneously, unequal crossing over and gene conversion homogenize tandemly arrayed gene copies in each cluster, leading to the observed pattern of concerted evolution. Therefore, we concluded that $5 \mathrm{~S}$ rDNA in fish genomes appears to evolve according to the mixed effects of concerted and birth-and-death evolution.

\section{Methods}

\section{Sampling, cloning and sequencing protocols}

Fresh samples of ten Potamotrygon falkneri, twelve Potamotrygon motoro (collected in Rio Paraná, Três Lagoas/ MS, Guaíra/PR and Foz do Iguaçu/PR, Brazil) and one Paratrygon aiereba specimen (collected in Rio Purus, Porto Velho/RO, Brazil) were subjected to genetic analysis. DNA was isolated from fins [84], and PCR amplifications of the $5 \mathrm{~S}$ rDNA were performed using the Cart5S1f (5'-CAC GCC CGA TCC CGT CCG ATC-3') and Cart5S1r (5'-CAG GCT AGT ATG GCC ATA GGC-3') primers. These oligonucleotides were designed by [30] based on the $5 \mathrm{~S}$ rRNA gene sequence of the elasmobranches Scyliorhinus caniculus (GenBank entry M24954) [85] and Taeniura lymma (GenBank entry AY278251) [86].

PCR amplifications were performed using 150 pmol of each primer, 20-80 ng of genomic template DNA, $1 \mathrm{x}$ Taq buffer, $200 \mu \mathrm{M}$ of dNTPs, and $1 \mathrm{U}$ of Taq polymerase (Invitrogen) in a final reaction volume of $25 \mu \mathrm{l}$. The cycling times were: $5 \mathrm{~min}$ at $94^{\circ} \mathrm{C}$; 35 cycles of $1 \mathrm{~min}$ at $95^{\circ} \mathrm{C}$ (denaturation), $30 \mathrm{~s}$ at $55^{\circ} \mathrm{C}$ (annealing) and $45 \mathrm{~s}$ at $72^{\circ} \mathrm{C}$ (elongation); and a final 5 min extension at $72^{\circ} \mathrm{C}$. A negative control was always included to determine if any contamination occurred. The PCR products were resolved in 1\% agarose gels and compared with a standard DNA marker (1Kb Plus Ladder - Invitrogen). Fragments were visualized after ethidium bromide staining, and the gel image was recovered using the EDAS program (Electrophoresis Documentation and Analysis System 120 - Kodak Digital Science 1D).

The PCR products were cloned into pGEM-T plasmids (Promega) and were used to transform DH5á
Escherichia coli competent cells. Positive recombinant clones were recovered and stored in $75 \%$ glycerol at $-80^{\circ}$ C. The positive clones were sequenced on an ABI Prism 3100 automatic DNA sequencer (Applied Biosystems) with a Dynamic Terminator Cycle Sequencing kit (Applied Biosystems) following the manufacturer's instructions.

\section{Phylogenetic analysis}

After remove vectors and primers sequences, we subjected nucleic acid sequences to BLASTn searches at the National Center for Biotechnology Information website (http://www.ncbi.nlm.nih.gov/blast). Next, sequence alignments were performed using MUSCLE [87], and consensus sequences were produced manually using BioEdit software [88].

Phylogenetic trees were generated by Bayesian Inference (BI), Maximum Likelihood (ML) and Maximum Parsimony (MP) methods employing the best fitting model of evolution, which was previously selected for each dataset following the Akaike Information Criterion (AIC) obtained with Modeltest 3.6 [41]. Maximim Likelihood trees were constructed with the PhyML program $[89,90]$ using a website version (http://hcv.lanl.gov/content/sequence/PHYML/interface.html). Gamma shape parameters and the proportion of non-variant sites were estimated by maximum likelihood from a neighbor-joining tree $(\mathrm{BIONJ})$. Maximum Parsimony trees were recovered in PAUP v4.0 [91] applying a branch-andbound search and treating insertions/deletions as missing data. The support for individual nodes in ML and MP trees were assessed by bootstrap resampling [92] using 1,000 replicates with random additions and TBR branch swapping. Bayesian Inference trees [93] were generated via the estimation of posterior probabilities using MrBayes v.3.0 [94]. Two runs of four continuoustime Markov chains were performed simultaneously for each dataset using default heating and sampling every 100 cycles. Each run was 1,000,000 steps long, and the asymptote of the likelihood score was detected with the SUMP command.

Genetic distances over all sequence pairs were obtained in MEGA 4 [95], with bootstrap for 1,000 replicates. All positions containing gaps in the alignment and missing data were eliminated in pairwise sequence comparisons. Nucleotide diversity and divergence were calculated with DnaSP v5 [96].

$5 \mathrm{~S}$ rDNA sequences representing the most important live lineages of vertebrates were retrieved from GenBank/EMBL/DDJB (See additional file 4: Compilation of information regarding $5 \mathrm{~S}$ rDNA nucleotide sequence in vertebrates) and were used in a comprehensive phylogenetic analysis. The majority-rule consensus (MRC) sequences of several Tetrapoda and Actinopterygii taxa 
were used to recover BI, ML and MP trees. Petromyzontifom lampreys were used as outgroup. Trees were visualized with the TreeExplorer program implemented in MEGA 4 [88].

\section{Southern blot hybridization}

Around $10 \mu \mathrm{g}$ of genomic DNA from P. falknerii, P. motoro and P. aiereba were completely digested with Pst $\mathrm{I}$, HindIII, PvuII and SspI endonucleases. These enzymes were selected based in their pattern of cut detected in the $5 \mathrm{~S}$ rRNA gene sequences. The restriction products were subjected to $1 \%$ agarose gel electrophoresis and transferred to a Hybond- $\mathrm{N}^{+}$nylon membrane by capillary blotting [77]. DNA hybridization was performed using as probes the 5S rDNA sequences from P. motoro and HindIII digested DNA of the tree species. For the final labeling and detection steps, we employed the ECL-Direct Nucleic Acid Labeling and Detection System kit (GE Healthcare Biosciences), following the manufacturer's instructions.

\section{Additional material}

Additional file 1: Final alignment of nucleotide sequences encompassing the class I and class II 5S rRNA genes from the three Potamotrygonidae stingrays. Species are referred to as follows: Pfalkneri $=$ Potamotrygon falkneri, Pmotoro $=P$. motoro, Paireba $=$ Paratrygon aiereba. Dots represent sequence identity, gray shadowed nucleotides are indicative of distinctive sites between 55 genes found in the two $5 \mathrm{~S}$ rDNA arrays. The internal control regions (A box, IE and C box) are highlighted in black. a, 5S rRNA genes class II; b, 5 S rRNA genes class 1 .

Additional file 2: NTS class I and NTS class II nucleotide sequences from the stingray species included in this study. a) Nucleotide sequence alignment of short NTS repetitions of class I; (b) partial nucleotide sequence alignments of long NTS repetitions of class II obtained from the stingrays genome. Species are referred to as follows: Pfalkneri $=$ Potamotrygon falkneri, Pmotoro $=$ P. motoro, Paireba $=$ Paratrygon aiereba. Dots represent conserved nucleotides and hyphens report indels. The microrepetition TCCC expanded in the P. aiereba genome is indicated in gray shading. Dots represent conserved bases and hyphens report indels.

Additional file 3: Alignment of $5 S$ rRNA gene sequences from several vertebrates. The $5 \mathrm{~S}$ gene of lampreys and diverse bony fish orders are majority-rule consensus (MRC) sequences obtained from data source listed in Additional file 1. (s) somatic type; (o) oocyte type. Sequences generated in the present study are underlined.

Additional file 4: Compilation of information regarding $5 S$ rDNA nucleotide sequence in vertebrates. $5 \mathrm{~S} \mathrm{rDNA}$ information of several vertebrate groups (except stingrays sequences) were retrieved from GenBank/EMBL/DDBJ and used in the present study.

\section{Acknowledgements and Funding}

The authors are grateful to Domingos G. Neto for sampling support. This work was funded with grants from FAPESP (Fundação de Amparo à Pesquisa do Estado de São Paulo) and CNPq (Conselho Nacional de Desenvolvimento Científico e Tecnológico), Brazil.

\section{Authors' contributions}

DP worked in the obtainment and analysis of nucleotide sequence data and drafted the manuscript. TSY and CSA helped in the DNA cloning and sequencing. CM designed and coordinated the study, and drafted and revised the manuscript. All authors read and approved the final manuscript.

Received: 9 February 2011 Accepted: 31 May 2011

Published: 31 May 2011

\section{References}

1. Long EO, Dawid IB: Repeated genes in Eukaryotes. Annu Rev Biochem 1980, 49:727-764.

2. Drouin G, Moniz de Sá M: The concerted evolution of $5 S$ ribosomal genes linked to the repeat units of other multigene families. Mol Biol Evol 1995, 12:481-493.

3. Arnheim N, Krystal M, Schmickel R, Wilson G, Ryder O, Zimmer E: Molecular evidence for genetic exchanges among ribosomal genes on nonhomologous chromosomes in man and apes. Proc Natl Acad Sci USA 1983, 77:7323-7327.

4. Dover G: Molecular drive: a cohesive mode of species evolution. Nature 1982, 299:111-116.

5. Arnheim N: Concerted evolution of multigene families. In Evolution of genes and proteins. Edited by: Nei M and Koehn RK. Sunderland: Sinauer; 1983:38-61.

6. Dover GA, Tautz D: Conservation and divergence in multigene families: alternatives to selection and drift. Phil Trans R Sot Lond B 1986, 312:275-289.

7. Dover GA: Molecular drive in multigene families: how biological novelties arise, spread and are assimilated. Trend Genet 1986, 2:161-165.

8. Freire $\mathrm{R}$, Insua $\mathrm{A}$, Méndez J: Cerastoderma glaucum $5 \mathrm{~S}$ ribosomal DNA: characterization of the repeat unit, divergence with respect to Cerastoderma edule, and PCR-RFLPs for the identification of both cockles. Genome 2005, 48:427-442.

9. Robles F, de la Herran R, Ludwig A, Rejon CR, Rejon MR, Garrido-Ramos MA: Genomic organization and evolution of the $5 S$ ribosomal DNA in the ancient fish sturgeon. Genome 2005, 48:18-28.

10. Keller I, Chintauan-Marquier IC, Veltsos P, Nichols RA: Ribosomal DNA in the grasshopper Podisma pedestris: escape from concerted evolution. Genetics 2006, 174:863-874.

11. Sword GA, Senior LB, Gaskin JF, Joern A: Double trouble for grasshopper molecular systematics: intra-individual heterogeneity of both mitochondrial 12S-valine-16S and nuclear internal transcribed spacer ribosomal DNA sequences in Hesperotettix viridis (Orthoptera: Acrididae). Syst Entomol 2007, 32:420-428.

12. López-Piñón MJ, Freire R, Insua A, Méndez J: Sequence characterization and phylogenetic analysis of the $5 \mathrm{~S}$ ribosomal DNA in some scallops (Bivalvia: Pectinidae). Hereditas 2008, 145:9-19.

13. Freire R, Arias A, Insua A, Méndez J, Eirín-López JM: Evolutionary dynamics of the $5 S$ rDNA gene family in the mussel Mytilus: mixed effects of birth-and-death and concerted evolution. J Mol Evol 2010, 70:413-426.

14. Ganal MW, Lapitan NLV, Tanksley SD: A molecular and cytogenetic survey of repeated DNA sequences in tomato (Lycopersicon esculentum). Mol Gen Genet 1988, 213:262-268.

15. Nedi MS, Rajagopal J, Chauhan N, Cronn R, Lakshmikumaran M: Length and sequence heterogeneity in $5 \mathrm{~S}$ rDNA of Populus deltoides. Genome 2002, 45:1181-1188.

16. Rooney AP, Ward TJ: Evolution of large ribosomal RNA multigene family in filamentous fungi: birth and death of a concerted evolution paradigm. Proc Natl Acad Sci USA 2005, 102:5084-5098.

17. Amici A, Rollo F: The nucleotide sequence of the $5 \mathrm{~S}$ ribosomal RNA gene of Pyrenophora graminea. Nucl Acids Res 1991, 19:5073.

18. Brown DD, Carroll F, Brown RD: The isolation and characterization of a second oocyte 5S DNA from Xenopus laevis. Cell 1977, 12:1045-1056.

19. Bogenhagen DF, Sakonju S, Brown DD: A control region in the center of the 5S RNA gene directs specific initiation of transcription II. The 3 'border of the region. Cell 1980, 19:27-35.

20. Bogenhagen DF, Brown DD: Nucleotide sequences in Xenopus 5S DNA required for transcription termination. Cell 1981, 14:261-270.

21. Komiya H, Hasegawa M, Takemura S: Differentiation of oocyte- and somatic-type 5 S rRNAs in animals. J Biochem 1986, 100:369-374.

22. Pendás AM, Moran P, Freije JP, Garcia-Vasquez E: Chromosomal mapping and nucleotide sequence of two tandem repeats of Atlantic salmon $5 \mathrm{~S}$ rDNA. Cytogenet Cell Genet 1994, 67:31-36. 
23. Móran P, Martínez JL, Garcia-Vásquez E, Pendás AM: Sex linkage of $5 \mathrm{~S}$ rDNA in rainbow trout (Oncorhynchus mykiss). Cytogenet Cell Genet 1996, 75:145-150.

24. Sajdak SL, Reed KM, Phillips RB: Intraindividual and interspecies variation in the 5S rDNA of coregonid fish. J Mol Evol 1998, 46:680-688.

25. Martins C, Galetti PM Jr: Organization of 5 S rDNA in Leporinus fish species: two different genomic locations are characterized by distinct non-transcribed spacers (NTSs). Genome 2001, 44:903-910.

26. Wasko AP, Martins C, Wright JM, Galetti PM Jr: Molecular organization of 5S rDNA in fishes of the genus Brycon. Genome 2001, 44:893-902.

27. Gornung E, Colangelo P, Annesi F: 5 S ribosomal RNA genes in six species of Mediterranean grey mullets: genomic organization and phylogenetic inference. Genome 2007, 50:787-795.

28. Campo D, Machado-Schiaffino G, Horreo JL, Garcia-Vazquez E: Molecular organization and evolution of $5 \mathrm{~S}$ rDNA in the genus Merluccius and their phylogenetic implications. J Mol Evol 2009, 68(3):208-216.

29. Pasolini $\mathrm{P}$, Costagliola D, Rocco L, Tinti F: Molecular organization of $5 \mathrm{~S}$ rDNAs in Rajidae (Chondrichthyes): structural features and evolution of piscine 5S rRNA genes and nontranscribed intergenic spacers. J Mol Evol 2006, 62:564-574.

30. Pinhal D, Araki CS, Gadig OBF, Martins C: Molecular organization of $5 \mathrm{~S}$ rDNA in sharks of the genus Rhizoprionodon: insights into the evolutionary dynamics of $5 \mathrm{~S}$ rDNA in vertebrate genomes. Genet Res 2009, 91:61-72.

31. Pinhal D, Gadig OBF, Martins C: Genetic identification of the sharks Rhizoprionodon porosus and $R$. lalandii by PCR-RFLP and nucleotide sequence analyses of 5 S rDNA. Conserv Genet Res 2009, 1:35-38.

32. Nei M, Hughes AL: Balanced polymorphism and evolution by the birthand-death process in the MHC loci. In 11th Histocompatibility workshop and conference. Edited by: Tsuji K, Aizawa M, Sasazuki T. Oxford: Oxford University Press; 1992:27-38.

33. Nei M, Gu X, Sitnikova T: Evolution by the birth-and-death process in multigene families of the vertebrate immune system. Proc Natl Acad SCi USA 1997, 94:7799-7806.

34. Nei M, Rogozin IB, Piontkivska H: Purifying selection and birth-and-death evolution in the ubiquitin gene family. Proc Natl Acad Sci USA 2000, 97:10866-10871.

35. Vierna J, Gonzalez-Tizon A, Martinez-Lage A: Long-term evolution of $5 \mathrm{~S}$ ribosomal DNA seems to be driven by birth-and-death processes and selection in Ensis razor shells (mollusca: Bivalvia). Biochem Genet 2009, 47:635-644.

36. Pinhal D, Gadig OBF, Wasko AP, Oliveira C, Foresti F, Martins C: Discrimination of shark species by simple PCR of 5 S rDNA repeats. Genet Mol Biol 2008, 31:361-365.

37. Thorson TB, Wooton RM, Georgi TD: Rectal gland of freshwater stingrays, Potamotrygon ssp. (Condrichthyes: Potamotrygonidae). Biol Bull 1978, 154:508-516.

38. Compagno LJV, Cook SF: The exploitation and conservation of freshwater elasmobranchs: status of taxa and prospects for the future. J Aquaric Aquat Sci 1995, 7:62-90

39. Nishida K: Phylogeny of the suborder Myliobatidoidei. Memoirs of the Faculty of Fisheries, Hokkaido University 1990, 37:1-108.

40. Pieler $\mathrm{T}$, Hamm J, Roeder RG: The $5 \mathrm{~S}$ gene internal control region is composed of three distinct sequence elements, organized as two functional domains with variable spacing. Cell 1987, 48:91-100.

41. Posada D, Crandall KA: Modeltest: testing the model of DNA substitution. Bioinformatics 1998, 14:817-818.

42. Martins C, Wasko AP, Oliveira C, Porto-Foresti F, Parise-Maltempi PP, Wright JM, Foresti F: Dynamics of 5S rDNA in the tilapia (Oreochromis niloticus) genome: repeat units, inverted sequences, pseudogenes and chromosome loci. Cytogenet Genome Res 2002, 98:78-85.

43. Martins C, Galetti PM Jr: Two 5S rDNA arrays in neotropical fish species: is it a general rule for fishes? Genetica 2001, 111:439-446.

44. Nederby-Nielsen J, Hallenberg C, Frederiksen S, Sorensen PD, Lomholt B: Transcription of human $5 S$ rRNA genes is influenced by an upstream DNA sequence. Nucleic Acids Res 1993, 26:3631-3636.

45. Suzuki H, Sakurai S, Matsuda Y: Rat 5S rDNA spacer sequences and chromosomal assignment of the genes to the extreme terminal region of chromosome 19. Cytogenet Cell Genet 1996, 72:1-4.
46. Lovejoy NR: Stingrays, parasites, and historical biogeography: A closer look at Brooks et al's hypotheses for the origins of neotropical freshwater rays: Potamotrygonidae. Syst Biol 1997, 46:218-230.

47. Lovejoy NR, Bermingham E, Martin AP: South American rays came in with the sea. Nature 1998, 396:421-422.

48. Underwood CJ: Diversification of the Neoselachii (Chondrichthyes) during the Jurassic and Cretaceous. Paleobiology 2006, 32(2):215-235.

49. Drouin G: Expressed retrotransposed 5S rRNA genes in the mouse and rat genomes. Genome 2000, 43:213-215.

50. Pelliccia F, Barzotti R, Bucciarelli E, Rocchi A: 5 S rRNA and U1 snRNA genes: a new linkage type in the genome of a crustacean that has three different tandemly repeated units containing $5 S$ rDNA sequences. Genome 2001, 44:331-335.

51. Raskina O, Belyayev A, Nevo E: Quantum speciation in Aegilops: molecular cytogenetic evidence from rDNA clusters variability in natural populations. Proc Natl Acad Sci USA 2004, 101:14818-14823.

52. Raskina O, Belyayev A, Nevo E: Activity of the En/Spm -like transposons in meiosis as a base for chromosome repatterning in a small, isolated, peripheral population of Aegilops speltoides Tausch. Chromosome Res 2004, 12:153-161.

53. Martins C, Ferreira IA, Oliveira C, Foresti F, Galetti PM Jr: A tandemly repetitive centromeric DNA sequence of the fish Hoplias malabaricus (Characiformes: Erythrinidae) is derived from 5S rDNA. Genetica 2006, 127:133-141.

54. Kress H, Bechler K, Swida U, Maletz S: Evolution of 5S rRNA gene families in Drosophila. Chromosome Res 2001, 9:403-415.

55. Trontin JF, Grandemange C, Favre JM: Two highly divergent 5S rDNA unit size classes occur in composite tandem array in European larch (Larix deciduas Mill.) and Japanese larch (Larix kaempferi (Lamb.) Carr.). Genome 1999, 42:837-848.

56. Falistocco E, Passeri V, Marconi G: Investigations of 5S rDNA of Vitis vinifera L.: sequence analysis and physical mapping. Genome 2007, 50:927-938.

57. Nei M, Rooney AP: Concerted and birth-and-death evolution in multigene families. Annu Rev Genet 2005, 39:121-152.

58. Pendás AM, Móran P, Martínez JL, Garcia-Vásquez E: Applications of $5 \mathrm{~S}$ rDNA in Atlantic salmon, brown trout, and in Atlantic salmon $\mathrm{x}$ brown trout hybrid identification. Mol Ecol 1995, 4:275-276.

59. Aranishi F: PCR-RFLP analysis of nuclear nontranscribed spacer for mackerel species identification. J Agric Food Chem 2005, 53:508-511.

60. Presa P, Pardo BG, Martínez P, Bernatchez L: Phylogeographic congruence between mtDNA and rDNA ITS markers in brown trout. Mol Biol Evol 2002, 19:2161-2175.

61. Ferreira IA, Oliveira C, Venere PC, Galetti PM Jr, Martins C: $5 \mathrm{~S}$ rDNA variation and its phylogenetic inference in the genus Leporinus (Characiformes: Anostomidae). Genetica 2006, 129:253-257.

62. Ohta T, Dover GA: The cohesive population genetics of molecular drive. Genetics 1984, 108:501-521.

63. Liao D: Gene conversion drives within genic sequences: converted evolution of ribosomal RNA genes in bacteria and archaea. J Mol Evol 2000, 51:305-17.

64. Anjard C, Loomis WF: Evolutionary analyses of ABC transporters of Dictyostelium discoideum. Euk Cell 2002, 1:643-52.

65. Eickbush TH, Eickbush DG: Finely orchestrated movements: evolution of the ribosomal RNA genes. Genetics 2007, 175:477-485.

66. Walsh JB: Sequence-dependent gene conversion: can duplicated genes diverge fast enough to escape conversion? Genetics 1987, 117:543-557.

67. Insua A, Freire R, Ríos J, Méndez J: The 5 S rDNA of mussels Mytilus galloprovincialis and $M$. edulis: sequence variation and chromosomal location. Chromosome Res 2001, 9:495-505.

68. Caradonna F, Bellavia D, Clemente AM, Sisino G, Barbieri R: Chromosomal localization and molecular characterization of three different $5 \mathrm{~S}$ ribosomal DNA clusters in the sea urchin Paracentrotus lividus. Genome 2007, 50:867-870.

69. Fujiwara M, Inafuku J, Takeda A, Watanabe A, Fujiwara A, Kohno S, Kubota S: Molecular organization of 5S rDNA in bitterlings (Cyprinidae). Genetica 2009, 135:355-365

70. Eirín-López JM, Gonzalez-Tizon AM, Martinez A, Mendez J: Birth-and-death evolution with strong purifying selection in the histone $\mathrm{H} 1$ multigene family and the origin of orphon $\mathrm{H} 1$ genes. Mol Biol Evol 2004, 21:1992-2003. 
71. Eirín-López JM, González-Romero R, Dryhurst D, Méndez J, Ausió J: Longterm evolution of histone families: old notions and new insights into their diversification mechanisms across eukaryotes. In Evolutionary Biology: Concept, Modeling, and Application. Edited by: Pontarotti P. Berlin, Heidelberg: Springer-Verlag; 2009:139-162.

72. Piontkivska H, Rooney AP, Nei M: Purifying selection and birth-and-death evolution in the histone $\mathrm{H} 4$ gene family. Mol Biol Evol 2002, 19:689-97.

73. Nikolaidis N, Nei M: Concerted and nonconcerted evolution of the Hsp70 gene superfamily in two sibling species of nematodes. Molec Biol Evol 2004, 21:498-505.

74. Zhang Z, Inomata N, Yamazaki T, Kishino H: Evolutionary history and mode of the amylase multigene family in Drosophila. J Mol Evol 2003, 57:702-709.

75. Hartmann S, Nason JD, Bhattacharya D: Extensive ribosomal DNA genic variation in the columnar cactus Lophocereus. J Mol Evol 2001, 53:124-134.

76. Mayol M, Rossello JA: Why nuclear ribosomal DNA spacers (ITS) tell different stories in Quercus. Mol Phyl Evol 2001, 19:167-176.

77. Márquez LM, Miller DJ, MacKenzie JB, van Oppen MJH: Pseudogenes contribute to the extreme diversity of nuclear ribosomal DNA in the hard coral Acropora. Mol Biol Evol 2003, 20:1077-1086.

78. Rooney AP: Mechanisms underlying the evolution and maintenance of functionally heterogeneous 18S rRNA genes in apicomplexans. Mol Biol Evol 2004, 21:1704-1711.

79. Kellogg EA, Appels R: Intraspecific and interspecific variation in 5S RNA genes are decoupled in diploid wheat relatives. Genetics 1995, 140:325-343.

80. McLysaght A, Hokamp K, Wolfe KH: Extensive genomic duplication during early chordate evolution. Nat Genet 2002, 31:200-204.

81. Dehal $\mathrm{P}$, Boore $\mathrm{JL}$ : Two rounds of whole genome duplication in the ancestral vertebrate. PLOS Biol 2005, 3:e314

82. Meyer $A$, Van de Peer $Y$ : From $2 R$ to $3 R$ : evidence for a fish-specific genome duplication (FSGD). BioEssays 2005, 27:937-945.

83. Martins C, Wasko AP: Organization and evolution of $5 \mathrm{~S}$ ribosomal DNA in the fish genome. In Focus on Genome Research. Edited by: Williams CR. Hauppauge: Nova Science Publishers; 2004:335-363.

84. Sambrook J, Russel DW: Molecular Cloning: A Laboratory Manual. New York: Cold Spring Harbor Laboratory Press; 2001.

85. Wegnez $M$, Denis $H$, Mazabraud A, Clerot JC: RNA accumulation during oogenesis of the dogfish Scyliorhinus caniculus. Biochemical research on oogenesis. Dev Biol 1978, 62:99-111.

86. Rocco L, Costagliola D, Fiorillo M, Tinti F, Stingo V: Molecular and chromosomal analysis of ribosomal cistrons in two cartilaginous fish, Taeniura lymma and Raja montagui (Chondrichthyes, Batoidea). Genetica 2005, 123:245-253.

87. Edgar RC: MUSCLE: multiple sequence alignment with high accuracy and high throughput. Nucl Acids Res 2004, 32(5):1792-1797.

88. Hall TA: BioEdit: a user-friendly biological sequence alignment editor and analysis program for Windows 95/98/NT. Nucl Acids Symp Ser 1999, 41:95-98.

89. Guindon S, Gascuel O: A simple, fast and accurate algorithm to estimate large phylogenies by maximum likelihood. Syst Biol 2003, 52:696-704.

90. Guindon S, Lethiec F, Duroux P, Gascuel O: PHYML Online - a web server for fast maximum likelihood-based phylogenetic inference. Nucl Acids Res 2005, 33:557-559.

91. Swofford DL: PAUP* Phylogenetic analysis using parsimony (*and other methods). Version 4b10. Sunderland: Sinauer Associates; 2002

92. Felsenstein J: Confidence limits on phylogenies: an approach using the bootstrap. Evolution 1985, 39:783-791.

93. Huelsenbeck JP, Ronquist F, Nielsen R, Bollback JP: Bayesian inference of phylogeny and its impact of evolutionary biology. Science 2001, 294:2310-2314.

94. Ronquist F, Huelsenbeck JP: MrBayes 3: Bayesian phylogenetic inference under mixed models. Bioinformatics 2003, 19:1572-1574.

95. Tamura K, Dudley J, Nei M, Kumar S: MEGA4: Molecular Evolutionary Genetics Analysis (MEGA) software version 4.0. Mol Biol Evol 2007, 24:1596-1599.

96. Librado P, Rosas J: DnaSP v5: A software for comprehensive analysis. Bioinformatics 2009, 25:1451-1452. doi:10.1186/1471-2148-11-151

Cite this article as: Pinhal et al:: The $5 \mathrm{~S}$ rDNA family evolves through concerted and birth-and-death evolution in fish genomes: an example from freshwater stingrays. BMC Evolutionary Biology 2011 11:151.

\section{Submit your next manuscript to BioMed Central and take full advantage of:}

- Convenient online submission

- Thorough peer review

- No space constraints or color figure charges

- Immediate publication on acceptance

- Inclusion in PubMed, CAS, Scopus and Google Scholar

- Research which is freely available for redistribution

Submit your manuscript at www.biomedcentral.com/submit
C) Biomed Central 